\title{
Peranan Credit Union dalam Mengatasi Persoalan Sosial Ekonomi di Kabupaten Kepulauan Tanimbar (Studi Kasus pada Credit Union Hati Amboina Saumlaki)
}

\author{
Martinus Lukas Kamamas ${ }^{1}$, Petrus Balak ${ }^{2}$, dan Titus Odong Kusumajati ${ }^{3}$ \\ ${ }^{1}$ Ekonomi Pembangunan, Sekolah Tinggi Ilmu Ekonomi Saumlaki, Indonesia \\ ${ }^{2}$ Akuntansi, Sekolah Tinggi Ilmu Ekonomi Saumlaki, Indonesia \\ ${ }^{3}$ Magister Manajemen, Fakultas Ekonomi, Universitas Sanata Dharma, Yogyakarta, Indonesia \\ martinuskamamas23@gmail.com, petrusbalak142@gmail.com, tituskusumajati@usd.ac.id
}

DOI: https://doi.org/10.24071/exero.v2i2.4049

\begin{abstract}
Abstrak
Penelitian ini bertujuan untuk mengkaji peran Credit Union Hati Amboina dalam menyelesaikan masalah kemiskinan yang dihadapi anggota. Penelitian ini menggunakan pendekatan kualitatif dengan metode triangulasi. Subyek penelitian ini adalah 100 orang anggota aktif Credit Union, 3 (tiga) orang pengurus, dan 2 (dua) orang pejabat pemerintah dari dinas koperasi. Data penelitian dianalisis dengan mengelompokkan data berdasarkan ragam data dan informasi yang diperoleh dari studi pustaka, dokumen, survei, wawancara dan observasi lapangan. Hasil penelitian ini menunjukkan bahwa keberadaan Koperasi Kredit Hati Amboina di Saumlaki mampu menyelesaikan permasalahan sosial ekonomi yang dialami anggota. Model yang diterapkan CU Hati Amboina untuk mengatasi permasalahan anggota adalah mendorong anggota untuk memanfaatkan semua produk simpan pinjam serta pendekatan pemberdayaan kepada setiap komunitas basis bisnis dan non bisnis. Namun, pencapaian Credit Union Hati Amboina belum maksimal karena pengaruh pandemi Covid-19.
\end{abstract}

Kata kunci: credit union, isu sosial, kesejahteraan, basis masyarakat

\begin{abstract}
This study aims to examine the role of Hati Amboina Credit Union in resolving the problem of poverty faced by members. This study uses a qualitative approach with the triangulation method. The subjects of this study were 100 active members of the Credit Union, 3 (three) administrators, and 2 (two) government officials from the government office of cooperatives. The research data were analyzed by classifying the data based on the variety of data and information obtained from literature, documents, surveys, interviews and field observations. The results of this study indicate that the presence of Hati Amboina Credit Union in Saumlaki is able to resolve socio-economic problems experienced by members. The model applied by Hati Amboina Credit Union to resolve the members' problems was encouraging members to take advantage of all loan and savings products as well as an empowerment approach to each business and non-business basis community. However, the achievement of Hati Amboina Credit Union was not at its maximum level due to the influence of the Covid-19 pandemic.
\end{abstract}

Keywords: credit union, social problems, welfare, basis community

\section{Pendahuluan}

Pemerintah telah selalu berusaha mengatasi masalah kemiskinan sebagaimana bisa dilihat dari diterbitkannya berbagai aturan dan kebijakan yang berkaitan dengan masalah kemiskinan. Misalnya, kebijakan pemberian subsidi bagi masyarakat tidak mampu, atau kebijakan Kartu Indonesia Pintar, Kartu Indonesia Sehat, dan 
sebagainya. Tujuan dari semua kebijakan tersebut adalah agar masyarakat terbebas dari cengkraman kemiskinan dan agar masyarakat bisa hidup sejahtera.

Namun demikian, penghapusan kemiskinan adalah upaya yang kompleks dan tidak mudah dilakukan. Berbagai kebijakan yang dikeluarkan pemerintah tersebut belum serta merta bisa menghapus kemiskinan masyarakat, sebagaimana ditunjukkan oleh kenyataan di berbagai daerah dimana masyarakat masih menghadapi persoalan kemiskinan. Salah satunya adalah masyarakat yang berada di Kabupaten Kepulauan Tanimbar.

Masyarakat miskin pada umumnya lemah dan tak berdaya. Menurut Sulistiyani (2004), kemiskinan dilihat dari sisi poverty profile masyarakat, kemiskinan tidak hanya menyangkut persoalan kesejahteraan (welfare) semata, tetapi kemiskinan menyangkut persoalan kerentanan (vulnerability), ketidakberdayaan (powerless), tertutupnya akses kepada berbagai peluang kerja, menghabiskan sebagian besar penghasilannya untuk kebutuhan konsumsi, angka ketergantungan yang tinggi, rendahnya akses terhadap pasar, dan kemiskinan terefleksi dalam budaya kemiskinan yang diwarisi dari satu generasi ke generasi berikutnya.

Bahkan kelompok miskin di berbagai negara tidak memiliki akses terhadap layanan keuangan (financial services). Ada dua faktor utama yang menghambat akses masyarakat pada sektor keuangan, yaitu faktor permintaan dan penawaran. Permintaan berkaitan dengan kurangnya kepedulian dan pengetahuan masyarakat terhadap jasa keuangan, rendahnya pendapatan, dan tidak adanya jaminan (collateral). Sedangkan dari sisi penawaran, beberapa faktor yang menghambat akses masyarakat pada layanan keuangan terutama yang disediakan oleh Lembaga-lembaga formal diantaranya karena jauhnya jarak cabang bank dengan tempat tinggal, prosedur yang rumit, ketidaksesuaian produk keuangan dengan kebutuhan, bahasa yang kurang dimengerti, perilaku pegawai, dan waktu operasi dari bank yang kaku (Ledgerwood, 2006).

Melihat permasalahan seperti yang telah diuraikan diatas maka saat ini dibutuhkan beberapa alternatif solusi nyata yang dapat membantu mengatasi permasalahan tersebut. Salah satu solusi tersebut adalah hadirnya salah satu lembaga keuangan mikro yaitu Credit Union Hati Amboina (CUHA), Saumlaki, yang dipercaya mampu menjawab persoalan kemiskinan dengan berbagai produk yang 
ditawarkan bagi anggota. Penelitian ini bertujuan untuk mengkaji peran Credit Union Hati Amboina dalam menjawab permasalahan kemiskinan yang dihadapi oleh anggotanya.

\section{Kajian Literatur}

Credit Union diambil dari bahasa Latin "Credere" yang berarti percaya dan "Union" atau "Unus" berarti kumpulan (Munaldus, dkk. 2012). Makna dari pengertian di atas adalah merupakan kumpulan orang-orang yang saling percaya untuk mengumpulkan modal dan modal tersebut dipinjamkan kepada sesama sebagai bagian dari proses peningkatan kesejahteraan anggota. Credit Union di Indonesia biasa dikenal sebagai koperasi kredit.

Credit Union adalah sebuah lembaga keuangan yang berbentuk koperasi yang menyediakan jasa-jasa keuangan sebagaimana diselenggarakan oleh lembaga perbankan seperti rekening tabungan dan rekening biro, pinjaman untuk berbagai tujuan, asuransi, dan jasa pengiriman uang sesuai dengan kebutuhan anggota dan perkembangan Credit Union (WOCCU, 2003). Pengertian di atas, secara khusus diartikan oleh Berthoud dan Hinton (1989), Credit Union adalah koperasi yang menawarkan pinjaman kepada anggotnya dan untuk melunasi pinjaman tersebut para anggota dapat mengumpulkan uang melalui tabungan.

Sedangkan Credit Union menurut Kusumajati (2012) merupakan koperasi yang paling murni (the purest form of-co-coperative), di mana para anggota sendiri yang mengelolah, memanfaatkannya sekaligus sebagai pemilik dari koperasi tersebut. Kusumajati menambahkan bahwa ada pembatasan dalam hal keanggotaan di mana anggota harus berasal dari suatu ikatan tertentu berdasarkan komunitas tempat tinggal, pekerjaan, agama, dan sebagainya, selain dari transaksi khusus yang diperuntukkan bagi anggota.

Adapun tujuan didirikan Credit Union adalah untuk melayani para anggotanya demi mencapai kesejahteraan. Maka, Credit Union dalam pengelolaanya tidak untuk mencari keuntungan seperti lembaga keuangan lain. Hal ini sesuai dengan definisi dari World Council of Credit Union (WOCCU) Credit Union sebagai "not-for-profit cooperative institution" (lembaga koperasi yang bukan untuk tujuan mencari keuntungan). 


\section{Metode Penelitian}

Credit Union diambil dari bahasa Latin "Credere" yang berarti percaya dan "Union" atau "Unus" berarti kumpulan (Munaldus, dkk. 2012). Makna dari pengertian di atas adalah merupakan kumpulan orang-orang yang saling percaya untuk mengumpulkan modal dan modal tersebut dipinjamkan kepada sesama sebagai bagian dari proses peningkatan kesejahteraan anggota. Credit Union di Indonesia biasa dikenal sebagai koperasi kredit.

Credit Union adalah sebuah lembaga keuangan yang berbentuk koperasi yang menyediakan jasa-jasa keuangan sebagaimana diselenggarakan oleh lembaga perbankan seperti rekening tabungan dan rekening biro, pinjaman untuk berbagai tujuan, asuransi, dan jasa pengiriman uang sesuai dengan kebutuhan anggota dan perkembangan Credit Union (WOCCU, 2003). Pengertian di atas, secara khusus diartikan oleh Berthoud dan Hinton (1989), Credit Union adalah koperasi yang menawarkan pinjaman kepada anggotnya dan untuk melunasi pinjaman tersebut para anggota dapat mengumpulkan uang melalui tabungan.

Sedangkan Credit Union menurut Kusumajati (2012) merupakan koperasi yang paling murni (the purest form of-co-coperative), di mana para anggota sendiri yang mengelolah, memanfaatkannya sekaligus sebagai pemilik dari koperasi tersebut. Kusumajati menambahkan bahwa ada pembatasan dalam hal keanggotaan di mana anggota harus berasal dari suatu ikatan tertentu berdasarkan komunitas tempat tinggal, pekerjaan, agama, dan sebagainya, selain dari transaksi khusus yang diperuntukkan bagi anggota.

Adapun tujuan didirikan Credit Union adalah untuk melayani para anggotanya demi mencapai kesejahteraan. Maka, Credit Union dalam pengelolaanya tidak untuk mencari keuntungan seperti lembaga keuangan lain. Hal ini sesuai dengan definisi dari World Council of Credit Union (WOCCU) Credit Union sebagai "not-for-profit cooperative institution" (lembaga koperasi yang bukan untuk tujuan mencari keuntungan). 


\section{Hasil Dan Pembahasan}

Anggota CUHA beragam dari aspek usia, gender, ras, dan agama, dan sampai dengan bulan Oktober 2020 berjumlah sebanyak 2.625 orang. Untuk mengelola ribuan anggota tersebut dibutuhkan mekanisme kontrol yang baik, sehingga pada tahun 2018 mulai diprogramkan pembentukan Komunitas Basis (Kombas), terdiri dari Kombas usaha sejenis, Kombas usaha tidak sejenis, dan Kombas non usaha. Berdasarkan hasil wawancara dengan staf di bidang diklat dan pemberdayaan, sampai saat ini sudah terbentuk 19 Kombas usaha sejenis, 1 Kombas usaha tidak sejenis, dan 11 Kombas non usaha. Jumlah anggota yang tergabung dalam kombas tersebut sebanyak 321 orang.

Visi CUHA yaitu menjadi Credit Union yang terpercaya dan profesional di Maluku melalui pemberdayaan anggota berbasis komunitas untuk meningkatkan kualitas hidup anggota. Sementara misi yang diemban adalah memberdayakan anggota berbasis komunitas melalui pendidikan dan pelayanan keuangan yang cerdas dan kompetitif sesuai dengan standar tata kelola Credit Union. Untuk mencapai visi dan menjalankan misi tersebut, CUHA berpegang pada slogan "CUHA katong pung hidup", dan nilai-nilai inti CUHA yaitu menjunjung tinggi kejujuran dalam bekerja, ber-empati terhadap realitas masyarakat untuk kehidupan harmonis, selalu berinovasi dan disiplin dalam pelayanan dan unggul, dan profesional oleh aktivis yang ber-amanah dan netral.

Melalui pelayanan, CUHA ingin mewujudkan kesejahteraan anggota, yaitu "Kebutuhan terpenuhi sesuai pada waktunya". Kebutuhan manusia menurut CUHA adalah kebutuhan sesuai dengan siklus hidup manusia, dari sejak kandungan, lahir, sekolah, menikah, memiliki rumah, memiliki anak, masa tua, dan akhirnya meninggal. Fase-fase kehidupan tersebut perlu dipersiapkan secara matang melalui produk simpanan/tabungan yang tersedia. Tujuan menabung adalah agar pada saat membutuhkan, telah tersedia uang di tabungan sehingga dapat dimanfaatkan, sesuai dengan tahapan hidup sebagaimana ditunjukkan oleh Gambar 1 berikut. 


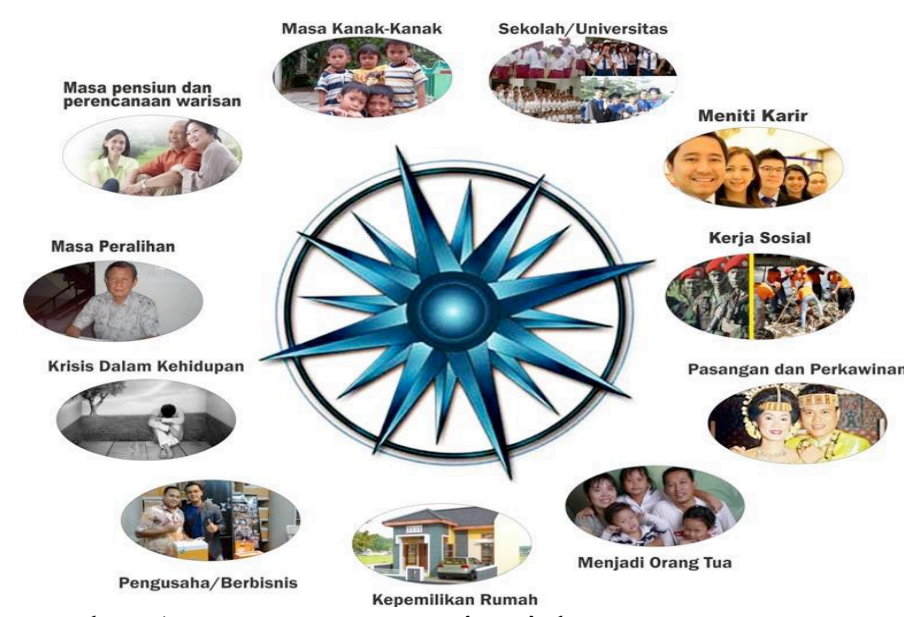

Gambar.1. Proses mencapai Sejahtera menurut CUHA (Bahan Pendidikan Dasar 2020 CUHA)

Sebagaimana dijelaskan pada latar belakang bahwa persoalan sosial seperti kemiskinan menjadi masalah utama di Indonesia, termasuk di Kabupaten Kepulauan Tanimbar. Masyarakat Tanimbar dikategorikan miskin karena berbagai faktor, yaitu tingkat pendidikan, pendapatan, keterbatasan akses kesehatan, keuangan dan pelayanan publik. Menurut data Badan Pusat Statistik (BPS) Provinsi Maluku 2019, jumlah penduduk miskin di Kabupaten Kepulauan Tanimbar sebanyak 30,76 ribu. Kemiskinan sendiri didefinisikan sebagai model kehidupan seseorang yang berada di bawa stadar kebutuhan sehari-hari manusia. Dampak dari kemiskinan adalah adanya penganguran. Penganguran melahirkan berbagai kriminal yang membuat kehidupan sosial masyarakat tidak aman.

Sebagai solusi atas persoalan sosial dan ekonomi, CUHA hadir dengan menawarkan berbagai produk simpanan dan pinjaman serta program-program pemberdayaan bagi anggota.

Terdapat 7 produk simpanan yang dapat dimanfaatkan oleh anggota: (1). Simpanan Kepemilikan (Simpanan Saham) merupakan modal yang dimiliki dan menjadi anggota sebagai pemilik CUHA, (2). Simpanan Dusun sebagai sebuah investasi untuk jangka panjang anggota, (3). Simpanan Lenso (simpanan harian) difungsikan untuk memenuhi kebutuhan sehari-hari, (4). Simpanan Sero (simpanan deposito) untuk investasi keuangan anggota dalam periode tertentu, (5). Simpanan Sasi (simpanan pendidikan) untuk persiapan dan pembiayaan pendidikan formal, (6). Simpanan Paparisa (simpanan perumahan) diperuntukkan untuk membeli tanah, membangun atau membeli rumah dan merenovasi serta merawat rumah, dan (7). 
Simpanan Darurat untuk meringankan beban anggota ketika mengalami masa sulit. Produk-produk simpanan tersebut dipercaya dapat membantu anggota untuk mencapai sejahtera.

Namun berdasarkan data yang diperoleh dari CUHA, ditemukan fakta bahwa anggota CUHA lebih memilih jenis simpanan yang masuk kategori simpanan wajib, yaitu Simpanan Saham, Simpanan Dusun, dan Simpanan Lenso, sedangkan simpanan lainnya hanya dipilih oleh sedikit anggota, seperti dapat dilihat pada Gambar 2, sebagai berikut:

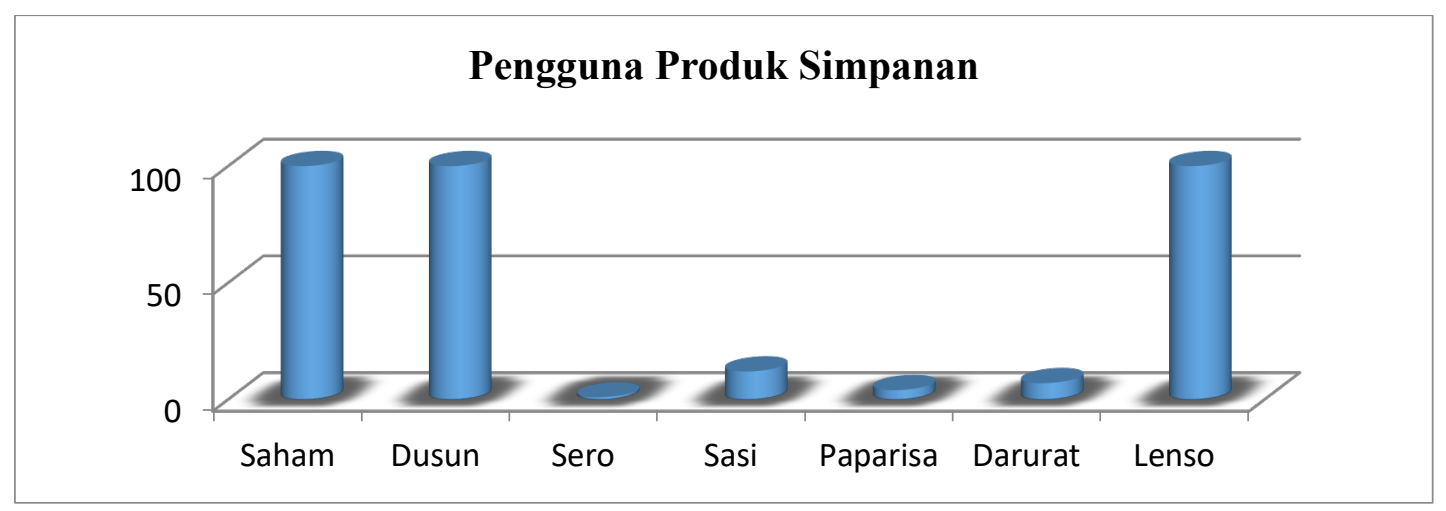

Gambar 2. Produk-Produk Simpanan yang digunakan oleh Anggota Sumber: Hasil pengolahan data

Gambar 2 menunjukkan bahwa semua anggota CUHA memanfaatkan Simpanan Saham, Simpanan Dusun, dan Simpanan Lenso. Sementara itu, Simpanan Sasi dimanfaatkan oleh 308 orang (atau 12\%), Simpanan Darurat diakses oleh 7\% anggota (atau 188 anggota), Simpanan Paparisa dimanfaatkan oleh 4\% anggota (atau 98 orang), dan Simpanan Sero dimanfaatkan oleh 21 orang anggota (atau 1\%).

Selain produk simpanan, juga ada produk pinjaman. Jumlah produk pinjaman di CUHA ada sebanyak 6 yaitu: (1). Pinjaman Menambah Simpanan, bertujuan untuk membangun kebiasaan menabung dan menambah modal pada Simpanan Dusun dan Simpanan Paparisa, (2). Pinjaman Produktif, difungsikan untuk meningkatkan pendapatan anggota melalui usaha produktif, (3). Pinjaman Konsumtif, yaitu pinjaman untuk memenuhi kebutuhan anggota seperti kesehatan, perabot rumah tangga, dan kendaraan, (4). Pinjaman Pendidikan, pinjaman untuk membantu anggota membiayai pendidikan anggota keluarga, (5). Pinjaman Paparisa, bermanfaat untuk membeli rumah, tanah dan sebagainya, dan (6). Pinjaman Komunitas, 
difungsikan untuk menambah pendapatan anggota yang terbentuk dalam komunitas.

Anggota yang memanfaatkan produk pinjaman jumlahnya bervariasi seperti ditunjukkan oleh Gambar 3 berikut.

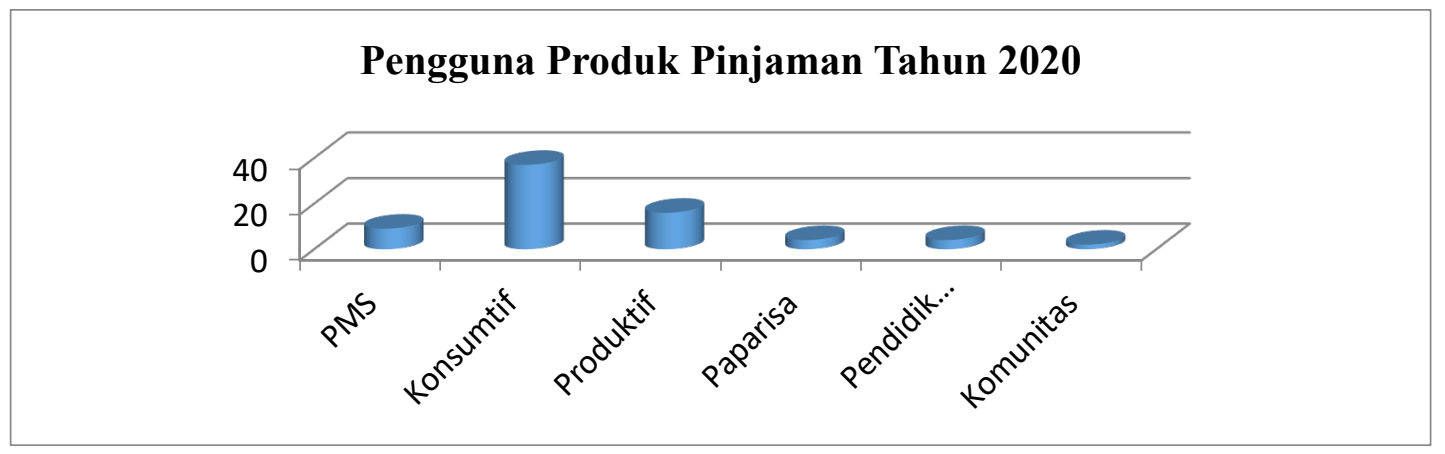

Gambar. 3. Pengunaan Produk-Produk Pinjaman oleh Anggota Sumber: Hasil pengolahan data

Gambar 3 di atas mengambarkan tentang kondisi anggota yang melakukan pinjaman. Sebagian besar anggota (37\% atau 964 orang) berminat pada pinjaman konsumtif, dan produk pinjaman yang paling sedikit peminatnya adalah pinjaman komunitas, yang hanya diambil oleh 42 orang (2\%). Pinjaman Produktif dimanfaatkan oleh 419 orang. Sementara Pinjaman Paparisa dan Pendidikan hanya diakses oleh $4 \%$ dari total anggota CUHA.

Berdasarkan data produk simpanan dan pinjaman, peneliti melihat bahwa anggota CUHA belum maksimal dalam memanfaatkan produk-produk tersebut. Walaupun demikian, data dari hasil kuesioner seperti yang tertera pada Gambar 4 di bawah, menunjukkan bahwa anggota merasakan manfaat di bidang ekonomi dan sosial setelah bergabung bersama CUHA. Gambar tersebut menjelaskan jawaban anggota atas pertanyaan penelitian tentang dampak yang diperoleh setelah bergabung dengan CUHA: 4\% narasumber menjawab tidak tahu, 7\% menyatakan bahwa bergabung dengan CUHA tidak membantu meningkatkan kehidupan ekonomi, dan 89\% narasumber menyatakan bahwa ada dampak positif setelah bergabung sebagai anggota CUHA. 


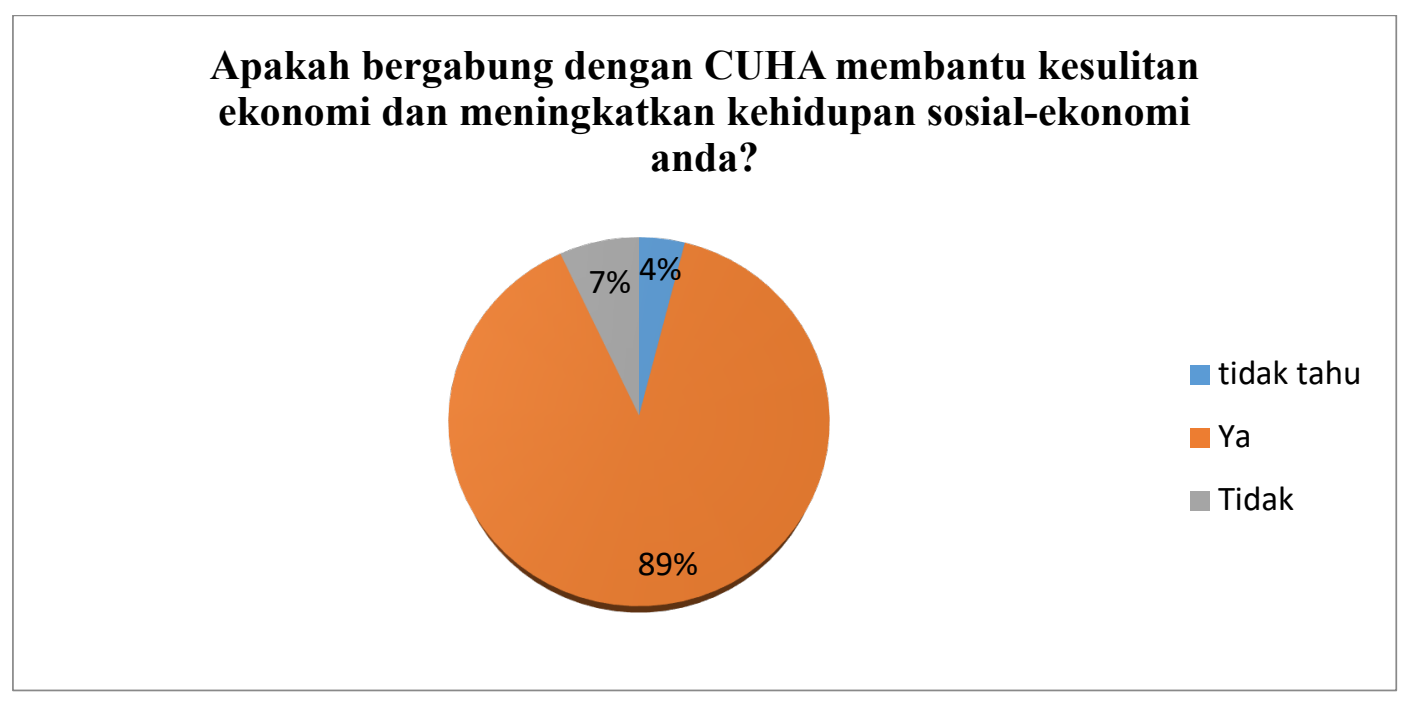

Gambar 4. Manfaat bergabung CUHA

Sumber: Hasil pengolahan data

Hasil survei tersebut sesuai dengan hasil wawancara peneliti dengan 10 orang ketua komunitas basis. Salah satu narasumber menyatakan bahwa pinjaman dari CUHA telah membantu menyekolahkan anaknya hingga perguruan tinggi dan sekarang sudah bekerja.

"beta masuk CUHA sangat bermanfaat untuk beta pun anak. Beta pun anak banyak tapi sudah kawin semua. Sisa satu anak terakhir. Beta sudah tua. Tapi bisa kerja kelapa par biaya anak kuliah. Beta kredit uang dari CUHA lalu kirim sama anak. Setiap bulan beta kerja buat sayur kacang panjang, kol kepala, cabe lalu istri pi jual di pasar Saumlaki. Trus bayar cicilan di kantor CUHA. Anak sudah wisuda dan sudah kerja” (Narasumber No. 5)

Narasumber lain juga mengatakan hal yang sama bahwa bergabung dengan CUHA telah membantu meningkatkan usahanya. Selama 10 tahun bergabung dengan CUHA telah memberi manfaat bagi keluarga.

"Dulu beta hanya usaha jual kue. Beta pun kue macam-macam. Tapi setelah gabung CUHA beta kredit untuk buka usaha minyak tanah dan telur. Sekarang sudah bisa beli motor untuk suami ojek. Jadi sekarang setiap hari kami punya pemasukan dari minyak tanah, telur, kue dan ojek dari suami" (Narasumber No. 2). 
Bahkan ada anggota yang mampu membeli sebuah mobil truck dan membuka usaha depot air minum. Pada hal sebelumnya suami bekerja sebagai sopir dan mereka hidup dari hasil pendapatan sebagai sopir yang serba sederhana. Ini dapat dilihat pada hasil testimoni anggota pada brosur CUHA.

"awalnya saya belum memiliki usaha, dan kehidupan keluarga kami dibiayai dari pendapatan suami sebagai sopir mobil pas-pasan bahkan tidak cukup. Saya bergabung dengan CUHA tanggal 12 April 2011, saya meminjam untuk membuka usaha dan hasil usahanya untuk membiayai pendidikan anak saya di seminari dan kebutuhan keluarga. Sedikit-demi sedikit saya menyimpan, dan pada akhirnya saya meminjam lagi untuk buka usaha yang baru (Depot air isi ulang) dan membeli 1 (satu) mobil truck sendiri untuk suami agar tidak lagi di bawah pimpinan orang lain” (Testimoni Anggota CUHA).

Pernyataan di atas didukung oleh keterangan salah satu staf CUHA pada Bidang Diklat dan Pemberdayaan. Anggota, yang menyatakan bahwa bergabung dengan CUHA tentu akan mengalami perubahan hidup apabila ada niat untuk menabung dan membuka usaha. Anggota yang dinyatakan layak untuk meminjam diyakini akan memiliki tanggung jawab dalam dirinya untuk menjaga usaha sehingga hasil usaha tersebut membantu kehidupan ekonomi keluarga dan melunasi angsuran kredit.

Salah satu staf yang lain juga menambahkan bahwa kehadiran CUHA adalah untuk mempermudah masyarakat dalam mengakses layanan jasa keuangan, seperti meminjam dan menyimpan. Masyarakat membutuhkan uang untuk proses transaksi demi memenuhi kebutuhan hidup. Namun demikian, masyarakat mengalami kesulitan untuk mengakses lembaga keuangan. Kalaupun bisa mempunyai akses, proses nya seringkali dirasakan sulit dan lama, karena untuk meminjam dibutuhkan berbagai persyaratan yang perlu disiapkan. Bagi masyarakat yang hidup di daerah pedesaan, dimana pengetahuan tentang akses keuangan masih minim, yang terjadi adalah uang yang diperoleh tidak disimpan untuk masa depan pendidikan anak atau memulai usaha, tetapi digunakan untuk membangun rumah. Apabila ada kebutuhan mendesak, maka masyarakat akan meminjam uang di rentiner dengan bunga pinjaman yang tinggi. 
Strategi CUHA dalam mendorong anggota untuk memanfaatkan berbagai produk pinjaman dan simpanan adalah dengan membentuk komunitas basis. Menurut staf Bidang Diklat dan Pemberdayaan CUHA, tujuan utama didirikan komunitas basis adalah agar masing-masing anggota dalam komunitas memiliki rasa kebersamaan dan tanggung jawab untuk menabung dan melunasi angsuran.

"Jumlah anggota CUHA sekarang sudah sekitar 2.625 orang. Kunjungi satu-satu orang sulit karena medan dan jarak yang lumayan jauh. Jadi atas kesepakatan bersama katong bentuk komunitas basis (kombas) di setiap kampong. Sampai sekarang sudah ada 31 kombas terbentuk. Ada 19 kombas usaha sejenis, kombas non usaha ada 11 dan satu kombas usaha tidak sejenis. Masing-masing kombas ada ketua. Ketua pun tugas kumpulkan anggota untuk pertemuan dengan petugas CUHA. Ketua juga diberi wewenang untuk tagih simpanan atau angsuran dari anggota, termasuk tagih kredit lalai."

Hal yang sama juga ditambahkan oleh Kepala Kantor Pelayanan CUHA bahwa kombas yang dibentuk mempunyai jumlah anggota yang berbeda-beda dengan jenis usaha berbeda pula. Kombas usaha sejenis terdiri dari 5-10 anggota, kombas non usaha dengan jumlah anggota sebanyak 15-25 orang, dan kombas usaha tidak sejenis berjumlah sekitar 30 orang. Sebagai contoh, kombas "Faduk" di desa Lorulun. Kombas ini berkonsentrasi pada peternakan babi, sedangkan kombas "Melsaie di desa Tumbur fokus untuk mengukir atau memahat kayu menjadi barang seni yang bernilai ekonomis, di desa Lauran memiliki kombas "Mnu Kote" yang bergerak di bidang perdagangan, kombas "Kayapa" di desa Kabiyarat memilih bidang usaha sayur-mayur yang dijual di pasar.

Senada dengan penjelasan staf Bidang Diklat dan Pemberdayaan, Kepala Kantor Pelayanan CUHA juga menambahkan bahwa setiap kombas dipimpin oleh seorang anggota yang dipandang mampu untuk mengkoordinir anggotanya. Tugas utama ketua kombas adalah menjadi mediator antara anggota dan kantor pelayanan CUHA. Sebagai ketua kombas berhak untuk menagih angsuran dan simpanan anggota sekaligus memberi dorongan kepada anggota yang lalai dalam proses pelunasan kredit. Ketua komunitas juga bekerjasama dengan CUHA untuk melaksakan 
berbagai kegiatan pendampingan dalam meningkatkan usaha anggota. Misalnya pendampingan tentang berwirausahaan, menanam sayur yang benar, berternak, dan budidaya ikan yang baik. CUHA menjadalkan setiap bulan ada pertemuan kombas dengan staf CUHA. Dalam pertemuan tersebut ketua kombas melaporkan segala persoalan yang dihadapi oleh anggota kombas. Bila ada kendala yang ditemukan maka akan dicari solusi oleh CUHA. sebagaimana keterangan dari stafi bidang diklat dan permberdayaan berikut:

"Kombas katong sudah bentuk tapi ada kombas yang gagal panen dan gagal berternak. Solusi yang katong ambil itu minta dinas Pertanian dan Peternakan untuk kasi pendampingan tentang tanam sayur yang benar dan ternak yang baik. Katong sudah tandatangan kerjasama dengan dinas-dinas terkait jadi kalau ada masalah pasti minta dinas untuk bantu sosialisasi”"

Pembentukan kombas ini bertujuan untuk mempermudah petugas CUHA agar secara rutin bertemu dengan anggota dalam proses pemberdayaan. Namun demikian, tahun ini proses pendidikan tidak dilakukan untuk kombas, walaupun sebelumnya sudah ditargetkan 7 kali pertemuan. Hal yang sama juga terjadi pada pertemuan untuk sosialisasi, pendidikan wajib CU, pendidikan penyegaran, pendidikan financial literacy. Penyebab utama tidak dilakukannya kegiatan-kegiatan tersebut adalah karena pandemi Covid-19, dimana masyarakat dilarang untuk berkumpul.

Secara umum, pendampingan terhadap kombas dalam tahun 2020 belum berjalan dengan maksimal. Menurut rencana, selama tahun 2020 akan dilakukan pendampingan kombas usaha sebanyak 138 kali, tapi baru 50 kali yang terealisasi. Pendampingan untuk kombas non usaha belangsung sebanyak 19 kali dari 178 kali yang ditargetkan. Sedangkan kombas usaha tidak sejenis belum pernah dilakukan pendampingan. Pandemi Covid-19 menjadi penyebab utama penurunan frekuensi pendampingan terhadap kombas. Covid-19 juga menyebabkan meningkatnya kredit lalai akibat dari menurunnya produktivitas usaha anggota.

Peneliti berpendapat bahwa pembentukan dan pemberdayaan kombas merupakan salah satu solusi dalam menjawab persoalan kemiskinan yang dihadapi oleh anggota di Kabupaten Kepulauan Tanimbar, walaupun terkendala dengan adanya Covid-19. Kombas telah memberikan manfaat, diantaranya adalah: menguatnya kerjasama antar anggota, saling menolong, dan saling mengingatkan untuk secara rutin 
melunasi kredit. Selain itu, kombas juga menjadi media promosi hasil usaha kepada sesama anggota dari kombas asal atau kombas lain, sebagai salah satu hasil nyata dari perubahan cara pelayanan CUHA, yang melengkapi pelayanannya dengan mulai mengintrodusir pelayanan secara online.

Perubahan sistem pelayanan ini menurut Kepala Pelayanan CUHA sangat membantu anggota CUHA. Kepala pelayanan CUHA menambahkan bahwa Anggota CUHA tidak boleh ketinggalan di era revolusi industri 4.0 yang ditandai dengan teknologi. Anggota CUHA mulai saat ini dapat mengakses segala jenis produk yang diikuti. Anggota bisa mengetahui jumlah simpanan dan pinjaman yang perlu diangsur hanya melalui handphone Android. Hasil usaha berupa ukiran, kerajinan tenun, bisnis sayur, daging, ikan dan sebagainya dapat dipromosikan melalui aplikasi yang disiapkan oleh CUHA. Aplikasi yang disediakan juga menolong anggota untuk membeli pulsa, membayar listrik, air dan mentransfer uang.

Dari berbagai penjelasan yang ditemukan, peneliti memahami bahwa kehadiran CUHA telah menjadi salah satu solusi meningkatkan kehidupan sosial ekonomi anggota melalui produk-produk simpanan dan pinjaman serta pendekatan pemberdayaan yang dilaksanakan. Anggota dinyatakan sejahtera bilamana mampu memanfaatkan produk-produk tersebut dan mengikuti segala program pemberdayaan CUHA. Kesejahteraan anggota menjadi tujuan utama kehadiran CUHA di Kabupaten Kepulauan Tanimbar.

\section{Kesimpulan, Implikasi, Saran dan Keterbatasan}

Berdasarkan analisis di atas, maka dapat disimpulkan bahwa kehadiran CUHA di Saumlaki telah terbukti mampu membantu anggota yang kesulitan memperoleh dana untuk memenuhi kebutuhan hidupnya. CUHA mampu memberi solusi atas persoalan sosial ekonomi yang dihadapi anggota di Kabupaten Kepulauan Tanimbar. Hal tersebut didukung oleh data penelitian yang menunjukkan bahwa $89 \%$ responden menyatakan bahwa CUHA telah membantu mengatasi kesulitan ekonomi yang dihadapi anggota, serta membantu meningkatkan kesejahteraan sosial ekonomi anggota. Hasil wawancara juga menyatakan bahwa CUHA hadir untuk membantu dan menolong anggota yang sulit memperoleh dana atau uang. Selain itu, CUHA menjawab permasalahan sosial ekonomi anggota dengan menyediakan berbagai produk simpanan dan pinjaman serta pemberdayaan berupa pembentukan komunitas 
basis (kombas). Namun demikian, upaya untuk memberdayakan anggota belum berjalan secara maksimal karena faktor pandemi Covid-19. Peneliti menyarankan agar CUHA mendorong anggota untuk memanfaatkan produk-produk simpanan dan pinjaman. CUHA, dan CUHA juga perlu mengintensifkan pendidkan dan pelatihan bagi anggota.

\section{Referensi}

Badan Pusat Statitik Nasional. (2019).

Badan Pusat Statistik (BPS) Provinsi Maluku. (2019).

Berthoud, R. and Hinton, T., 1989, Credit Unions in the United Kingdom, Policy Studies Institute, Printer Publishers Limited (UK).

Creswell. (2014). Research Design: Qualitative, Quantitative, and Mixed Methods Approaches (Fourth Ed.). Thousand Oaks, California: Sage Publications.

Kusumajati, Titus Odong. (2012). Faktor Ekonomi dan Kelembagaan Dalam Keberlanjutan Credit Union di Indonesia. (Disertasi Doktoral Tidak Dipublikasikan). Universitas Gadjah Mada. Yogyakarta. Indonesia.

Ledgerwood, Joanna, (2006), Transforming microfinance institutions: providing full financial services to the poor, The World Bank, Washinton, USA.

Munaldus, Yuspita Karlena, Yohanes RJ, Saniansah, dan B. Hendi. (2012). Credit Union Kendaraan Menuju Kemakmuran, Praktik Bisnis Sosial Model Indonesia. Jakarta: PT. Elex Media Komputindo, Kompas Gramedia.

Robinson, Marguerite S. (2011). The Microfinance Revolution; Sustainable Finance for the Poor. Washington, DC, the World Bank.

Sulistiyani, A.T. (2004). Kemitraan dan Model-Model Pemberdayaan. Yogyakarta: Gava Media.

WOCCU, (2003), “A Technical Guide to Rural Finance: Exploring Products", WOCCU Technical Guide \#3, December 2003, http:/www.woccu.org/ developmentguide/RF tech.pdf.

Triyani, Sinta. (2016). Peran Program Pendidikan Dalam Upaya Peningkatan Kapasitas Pengelolaan Keuangan yang Berdampak Pada Kesejahteraan Anggota Credit Union (Tesis Univeritas Sanata Dharma).Yogyakarta. Indonesia. 